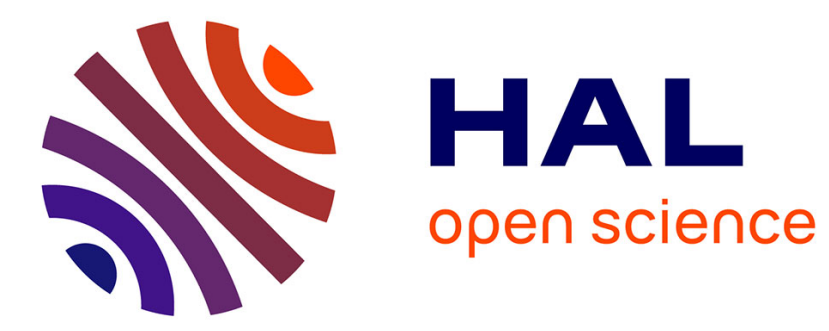

\title{
Performance of 12UD pelletron tandem accelerator
}

J. Sanada, S. Seki, T. Ishihara, Y. Nagashima, T. Mikumo, M. Yamanouchi, K. Katori, K. Kuriyama, K. Furuno, T. Aoki

\section{To cite this version:}

J. Sanada, S. Seki, T. Ishihara, Y. Nagashima, T. Mikumo, et al.. Performance of 12UD pelletron tandem accelerator. Revue de Physique Appliquée, 1977, 12 (10), pp.1340-1340. 10.1051/rphysap:0197700120100134000 . jpa-00244320

\section{HAL Id: jpa-00244320 https://hal.science/jpa-00244320}

Submitted on 1 Jan 1977

HAL is a multi-disciplinary open access archive for the deposit and dissemination of scientific research documents, whether they are published or not. The documents may come from teaching and research institutions in France or abroad, or from public or private research centers.
L'archive ouverte pluridisciplinaire HAL, est destinée au dépôt et à la diffusion de documents scientifiques de niveau recherche, publiés ou non, émanant des établissements d'enseignement et de recherche français ou étrangers, des laboratoires publics ou privés. 


\title{
PERFORMANCE OF 12UD PELLETRON TANDEM ACCELERATOR
}

\author{
J. SANADA, S. SEKI, T. ISHIHARA, and Y. NAGASHIMA \\ Tandem Accelerator Center, University of Tsukuba, Japan
}

T. MIKUMO, M. YAMANOUCHI, K. KATORI, K. KURIYAMA, K. FURUNO, and T. AOKI

Institute of Physics, University of Tsukuba, Japan

\begin{abstract}
Résumé. - Les performances de l'accélérateur 12UD de l'université Tsukuba sont décrites.
Abstract. The performance of the 12UD accelerator in Tsukuhal are descrihed.
\end{abstract}

The 12UD accelerator is now in use for researches in nuclear physics, atomic physics, biology, and medical science.

Regular machine time started on november 10, 1976. Total hours for chain running and beam running up to february 8,1977 are 1700 and $560 \mathrm{~h}$, respectively. In this period the accelerator ran at terminal voltages between 3.5 and 11.5 MV and behaved excellently without tank opening.

Ion species for routine use are; $\mathrm{p}(1 \mu \mathrm{A}), \mathrm{d}(1 \mu \mathrm{A})$, ${ }^{4} \mathrm{He}(0.1 \mu \mathrm{A}),{ }^{16} \mathrm{O}^{6+}(0.1 \mu \mathrm{A})$, and ${ }^{35} \mathrm{Cl}^{8+}(0.1 \mu \mathrm{A})$.

For helium negative ion production, the Cs-cell of the Lambshift polarized ion source was utilized as an electron adder.

Sulphur acceleration was tried. The current (analyzed charge current of $0.02 \mu \mathrm{A}$ for $\mathrm{S}(8+)$ ) was limited by deterioration of vacuum in the low energy tube. An additional pumping and trapping station will be necessary for using chemically active source gases.

Performance of NEC's electron trap was tested for chlorine run. The trap seemed inefficient to remove electrons stripped from heavy ions. Rather, when the trap was turned on, X-ray yield from the terminal area increased slightly. Increase by $40 \%$ of the magnetic field in the trap is scheduled.

Table I shows an example of data for routine operation.

\section{TABLE I}

Preaccel. volt. (kV)

Terminal volt. (MV)

Stripper* lifetime (h)

$$
\begin{array}{ccc}
35 \mathrm{Cl}^{8}+ & 16 \mathrm{O}^{6+} & \mathrm{P} \\
- & - & - \\
120 & 126 & 130 \\
11.35 & 10.45 & 7.24 \\
2 & 6 & \text { very long }
\end{array}
$$

Vacuum $^{* *}$; Low energy tube $\quad 4.0 \quad 3.8 \quad 3.0$

(x10-8 torr)

$\begin{array}{llll}\text { High energy tube } \quad 2.0 & 1.0 & 2.2\end{array}$

$\begin{array}{llll}\text { Charging current }(\mu \mathrm{A}) & 114 & 90 & 107\end{array}$

$\begin{array}{llll}\text { Lost current }(\mu \mathrm{A}) & 20 & 7 & 1.5\end{array}$

Accel. transmission (\%) $\quad 26 \quad 63 \quad 76$

Analyzed ion current $(\mu \mathrm{A}) \quad 0.11 \quad 0.7 \quad 1.3$

$\left(^{*}\right)$ Carbon foil, $10 \mu \mathrm{g} / \mathrm{cm}^{2}$.

(**) Vac. without beam : LE., 2; HE., 5 ( $\times 10^{-9}$ torr).

$(* * *)$ Charge current.

$(* * *)$ ( urrent for $\Delta l_{p}$, $2 \times$ hel 